DOI https://doi.org/10.30525/978-9934-26-114-5-8

\title{
КОМПЕТЕНТНОСТНЫЙ ПОДХОД В ОБРАЗОВАНИИ: ПСИХОЛОГИЧЕСКОЕ СОДЕРЖАНИЕ ОСНОВНЫХ ПОНЯТИЙ
}

\author{
Шаповал И. Н. \\ кандидат психологических наук, \\ дочент кафедры практической психологии \\ Криворожский государственный педагогический университет \\ 2. Кривой Рог, Днепротровская область, Украина
}

В условиях развития современной системы образования Украины происходит внедрение компетентностного подхода, который обусловил не только разработку и легитимизацию Стандартов высшего образования [1], но и необходимость трансформации самого образовательного процесса, включая как его нормативное и методическое обеспечение, так и разработку его научно-методологических обоснований.

В центре внимания высшей школы как образовательной организации - личность студента, которая находится в постоянном развитии в направлении профессионального становления по индивидуально неповторимой траектории развития. Результатом такого развития является профессиональная компетентность специалиста. Однако следует отметить, что в современных психолого-педагогических науках нет единого и согласованного понимания феноменов «компетентность» и «компетенция», что затрудняет разработку результативно-целевой основы и методической составляющей образовательно-профессиональной подготовки специалистов.

Среди разнообразных толкований обозначенных понятий, на наш взгляд, наиболее обоснованным и стройным является подход И. Зимней [2]. Автор указывает на то, что компетентность выступает в качестве интегрального личностного конструкта, формирующегося на базе и фундаменте компетенций, которыми владеет субъект образовательнопрофессионального процесса, и являющегося их интеллектуально обусловленным и мотивированным воплощением в решении разнообразных задач профессионально деятельности. Раскрывая сущность понятия «компетенция», И. Зимняя указывает на три его трактовки: педагогическая (компетенции как объективно заданная, структурированная и дидактически организуемая система определенного круга знаний, умений и навыков); психолого-практическая (компетенции как способности, т. е. комплекс индивидуально-психологических 
свойств личности, определяющих успешность и эффективность ее деятельности, в частности профессиональной); психолингвистическая (компетенция как внутреннее потенциальное когнитивное образование, как образ содержания знаний, программ их реализации, а также соответствующих способов действий).

По нашему мнению, понимание компетентности личности как способности является вполне обоснованным, поскольку сущность первой полностью отражает психологическую природу феноменологии вторых. В широком смысле способности понимаются как психические свойства, соответствующие определенному психическому процессу или психической деятельности и воплощающие форму связи субъекта с объективным миром [5]. Эти свойства сформировались в процессе общественно-исторического развития человечества, закрепились и передаются от поколения к поколению в виде предметов человеческой культуры как способа существования. Необходимым условием развития способностей индивида является овладение продуктами культуры на основе усвоения принципа их построения. Для того, чтобы человек овладел достижениями человечества, он должна, во-первых, осуществить по отношению к ним активную и адекватную деятельность, то есть такую, которая аккумулирована в этих предметах и явлениях и, тем самым, воплощает человеческие способности; и во-вторых, вступить в отношение к этим предметам и явлениям через других людей, то есть в процессе общения с ними, в котором он учится адекватной деятельности [3].

Деятельность индивида по присвоению предметов культуры будет адекватной при условии выполнения им общественно выработанных, исторически сложившихся операций, усвоение которых обеспечивается генерализацией существенных для данной отрасли человеческой активности отношений, которые, в свою очередь, заложены в каждом предмете как принцип его построения. Овладение такими операциям, а также генерализация предметно-отраслевых внутренних отношений основаны на механизмах обобщения психических процессов, функционирующих в деятельности и обеспечивающие ее выполнение [5]. Причем такое обобщение психических процессов является условием их перехода в психические свойства и обеспечивает перенос действий индивида из одних условий в другие, который выступает в качестве главного критерия определения свойств как способностей [4].

Способности соотносятся не с каким-либо отдельным психическим процессом, а с их комплексом, который выступает в качестве функционально системы как совокупности познавательных и 
психомоторных процессов: познавательные процессы обеспечивают реализацию функции отражения, психомоторные процессы - адекватное реагирование и влияние на окружающих. Таким образом, в узком смысле способности понимаются как свойства познавательных и психомоторных процессов, регулирующих реализацию определенной деятельности [6].

Исходя из выше изложенного, будем трактовать профессиональную компетентность как интегральную актуальную способность, которая определяет количественно-качественные показатели профессиональной деятельности: успешность овладения ее новыми способами и приемами, а также продуктивность и эффективность применения уже имеющихся в наличном профессиональном опыте. Профессиональные компетенции при этом выступают в качестве потенциальных способностей, т. е. таких, которые определяют степень и характер осведомленности субъекта в определенной профессиональной сфере, и могут быть реализованы в условиях конкретных практический ситуаций и задач. Следует заметить, что профессиональные ситуации и задачи характеризуются комплексностью проблематики, а также неопределённостью условий и требований. поэтому выделяются два аспекта профессиональных компетенций: 1) система профессиональных когнитивных и деятельностных представлений (знаний, умений, навыков) и 2) способность интерпретировать профессиональные задачи на основе обобщения и генерализации внутреннего содержания и специфических характеристик этих задач.

Причем для того, чтобы интерпретация профессиональных задач нашла свою реальную практическую воплощенность, субъект профессиональной деятельности должен обладать также определёнными личностными характеристиками, которые можно квалифицировать как профессионально важные качества и отнести к третьему личностному - аспекту профессиональных компетенций. Исходя из описанной психологической природы профессиональной компетентности, нами были определены следующие личностные компетенции: практико-ориентированный интеллект (способность подбирать, создавать и эффективно воплощать интеллектуальные стратегии для решения профессиональных задач), целеустремленность (способность к перспективному и актуальному целеполаганию, подчинение системы профессиональных действий достижению цели), ориентирование на эффективность и качество (способность к оптимальному использованию профессиональных ресурсов при сохранении качества конечного результата), ответственность (способность принимать независимые и обдуманные решения, нести ответственность за свои решения и за 
качество результатов своего труда), профессиональная мобильность, (способность адаптироваться при изменении профессиональной ситуации, психологическая готовность к инновациям в профессиональной деятельности), самостоятельность и креативность (способность генерировать новые идеи, готовность к нестандартному поведению в профессиональных ситуациях), информационная культура (способность находить и анализировать информацию, необходимую для эффективного решения профессиональных задач), способность к саморазвитию (стремление постоянно совершенствовать собственные качества и профессиональную деятельность), рефлексивная культура (способность адекватно и критически оценивать степень эффективности собственных профессиональных действий).

Таким образом, наличие профессиональных компетенций (определенной степени осведомленности в сфере профессиональной деятельности) определяется как потенциальная возможность формирования и реализации профессиональной компетентности (определенной степени владения профессиональной деятельностью).

\section{Литература:}

1. Затверджені стандарти вищої освіти / Міністерство освіти і науки України. URL: https://mon.gov.ua/ua/osvita/visha-osvita/naukovometodichna-rada-ministerstva-osviti-i-nauki-ukrayini/zatverdzheni-standartivishoyi-osviti (дата звернення: 13.07.2021).

2. Зимняя И. А. Компетенция и компетентность в контекст компетентностного подхода в образовании. Иностранные языки в школе. 2012. № 6. С. 2-10.

3. Леонтьев, А. Н. Об историческом подходе в изучении психики человека. Избранные психологические произведения. Т. 1. Москва: Педагогика, 1983.С. 96-141.

4. Мерлин В. С. Психология индивидуальности: избранные психологические труды: 2-е изд., стер. Москва: МПСИ; НПО «МЭДОК», 2009. 544 с.

5. Рубинштейн С. Л. Основы общей психологии. СанктПетербург: Питер, 2015. 705 с.

6. Шадриков В. Д. К новой психологической теории способностей и одаренности. Психологический журнал. 2019. Т. 40. № 2. C. 15-26. DOI: 10.31857/S020595920002981-5.

7. Психолого-педагогічні проблеми в освіті (загальної психології, вікової та педагогічної психології та ін.). 